\section{考察}

PTCA カテーテルシステムの改良と PTCA 技術の 向上により動脈解離や穿孔などの合併症は低下し，さら に大動脈バルーンパンピングや reperfusion catheter などの積極的な導入により failed PTCA に対する緊 急 CABG の発生頻度は 4 7\% 亿低下した ${ }^{1,2}$. Failed PTCA に対し待機的 CABG を行った場合の術中梗塞 の発生頻度は 4 6\%, 手術死亡率は 1\% 以下であるが, failed PTCA 亿対する緊急 CABG 例では, 術中梗塞 は 22 27\%, 手術死亡率む 0 11\%（平均 6.1\%）と待 機的 CABG 例と比べ明らか沉高い值を示している

自験例で屯同様の傾向がみられ，待機的に CABGを 行った群では, EF は不変あるいは軽度改善した。一 方, failed PTCA のためショックに宿り ST 上昇をき たした 2 例では, 発症 3 時間 39 分および 4 時間 50 分後 にバイパスを完成させたが，ともに心筋梗塞への移行を 防ぐことはできず，心機能は低下した。

Re-CABG の頻度は 2 6\% ${ }^{3,4}$ で, その問題点として は, 心膜の剝離, 心筋保護法 (antegrade 法, retrograde 法), 再建動脈の同定, 動脈送血部位, グラフトの選 択，グラフト中枢側の吻合部位，などがある，自験の Re-CABG は 3 例と少ないため問題点倿対する統一的見 解を述べることはできないが，現時点では胸骨縦切開を 注意深く行い，大腿動脈送血下に antegrade 法で心筋
保護を図り，血行再建を行っている．用いたグラフトは すべて大伏在静脈で， 2 例では従来どおりのバイパス術 を，1例では静脈片によるパッチ搪大術を行った．グラ フト全体に狭窄が及九でいる場合にはこの術式は使えな いが，限局性の狭窄に対しては応用可能と考えている。 本法を用いた症例 3 では再手術後 7 か月の現在, 虚血症 状や虚血サインをみていない，今後定期的にグラフト造 影や心負荷試験を行っていく予定である.

\section{結 論}

1) Re-CABG 例では手術死亡はなかったが，RePTCA 例で 1 例の近接死をみた。

2）臨床症状や心負荷試験の改善度は，PTCA 群よ りも CABG 群のほうが高かった。

3) $\mathrm{CABG}$ 後の PTCA により臨床症状の改善は得 られるものの狭窄の完全な解消は困難であり，厳重な経 過観察が必要である.

4） PTCA 後の長期経過例では，拡張不成功部だけ でなくその中枢側に病変の進行をみることがあり,バイ パス術に際し注意を要する。

文 献 1) Naunheim, K. S. et al.: Ann. Thorac. Surg. 47: 816, 1989. 2) Talley, J. D. et al. : Circulation 79 (Suppl. 1): 126, 1989. 3) Loop, F.D. et al.: J. Thorac. Cardiovasc. Surg. 81 : 675, 1981. 4) Foster, E. D. : Circulation 72 (Suppl. 5) : 59, 1985.

\title{
245 冠動脈再手術におけるわれわれの留意点
}

\section{湘原記念病院 心臟外科 \\ 榊原高之維田隆夫恒元秀夫 万納寺栄一 川 瀬 光 彦}

冠動脈バイパス手術 (CABG) は, グラフトの長期開 存性の問题があり, 冠動脈病変自身の進行之併せて今後 ますます再手術症例が増加すると予測される11.われわ れむ今後の治療のため, 今までの経験例を検討し問題点 を整理した。

\section{対 象}

1977 年 11 月より 1989 年 12 月までに当院で手術した
669 例の冠動脈外科手術症例中 14 例（2.0\%）につきそ の臨床経過を調べた３例は 3 回以上の多重回手術で あった. 外傷後のグラフト損傷 1 例を除き, 全例の手術 理由は狭心症または心筇梗塞の発生によるものであった (表 1 ).

手術は 1 本バイパス 6 例， 2 本バイパス 7 例，その他 損傷孔閉鎖などの処置を行った胸動脈は 10 例で使用し た. 前回手術時よりの時間は, 半数が 1 年以内, 最長 12 
表 1 冠血行再建多重回手術の成績とグラフト開存率

\begin{tabular}{|c|c|c|c|c|}
\hline \multicolumn{2}{|c|}{$\begin{array}{l}\text { 再冠血行再建手術症例 } \\
3 \text { 回以上の再手術症例 }\end{array}$} & \multicolumn{3}{|c|}{$\begin{array}{l}11 \text { 例（死亡0 例) } \\
3 \text { 例 (死亡 } 2 \text { 例) }\end{array}$} \\
\hline 合 & 計 & & 14 例（死亡 & 2 例) \\
\hline 再使用グラフト & 開存 & 閉塞 & 未検査 & $\begin{array}{l}\text { グラフト } \\
\text { 開存率* }\end{array}$ \\
\hline SVG & 2 本 & 5 本 & 3本 & $29 \%$ \\
\hline IMA & 5 本 & 0 本 & 6 本 & $100 \%$ \\
\hline
\end{tabular}

* 未検查を除く. (SHI 1989.12)

表 2 冠血行再建手術症例に対する PTCA の成績

\begin{tabular}{crrr}
\hline \multirow{2}{*}{$\begin{array}{c}\text { 狭窄グラフト } \\
\text { 怙よび冠動脈 }\end{array}$} & \multicolumn{2}{c}{ PTCA } & \multirow{2}{*}{$\begin{array}{c}\text { PTCA } \\
\text { 成功率 }\end{array}$} \\
\cline { 2 - 3 } & 成功 & 不成功 & \\
\hline SVG & 16 本 & 9 本 & $64 \%$ \\
IMA & 0本 & 2 本 & $0 \%$ \\
自己冠動脈 & 21 本 & 12 本 & $64 \%$ \\
\hline & & &
\end{tabular}

年，平均 48.6 か月であった。

\section{結果}

死亡は 2 例でいずれす 3 回以上の多重回手術症例でそ の死因は低心拍出症候群 (LOS) であった，生存例では 全例症状は著明に改善した。合併症は，開胸時右室損傷 1 例, 手術以前よりある肝障害の悪化 1 例のみであっ た。

使用した大伏在静脈グラフト 10 本, 内胸動脈 11 本の うち, 術後 1 年の精査を済ませたものでは, 大伏在静脈 では 7 本中 2 本のみが開存し開存率 $29 \%$ と悪かったが, 内胸動脈では 5 本全例， $100 \%$ の開存率であった，術後 患者に打壮る, 大伏在静脈 25 本, 自己冠動脈 33 本に対 する PTCA の成功率はいずれす $64 \%$ であった(表 2 ).

\section{考察}

再手術の多い米国では，死亡率むグラフトの開存率む 初回と同様浪好であると報告されている
表 3 多重回手術における冠血行再建手術に対する工夫

1. 心不全に対する積極的な IABP の使用

2. 初回手術時のグラフトの温存 SVG は一側下肢より採取, IMA あるいは GEA の うち 1 本は温存

3. 再使用するグラフトの術前状態の検索

4. 術中心筋梗塞の予防 IABP や逆行性冠灌流の併用

5. 術中手術操作を容易にする 人工心肺の大腿動脈送血, 右房 1 本脱血

6. 旧閉塞グラフトを目印とした吻合部の確認と CUSA を用いた冠動脈の露出

7. 人工血管, 保存生体血管, 下腹壁動脈等利用の可能性

れの症例数はまだ少ないので明確なととはいえないが， 初回に続く再手術の成績はよい. しかし，大伏在静脈グ ラフトの開存性は墨く, 内胸動脈に比較しその効果を信 頼できない.

一方, 術後患者に対する PTCA の成績も悪く, 合併 症発生時の緊急手術の対応は難しい.グラフト全閉塞の 患者でむ, 意外にリハビリ・内科療法の効果がみられ る. 内胸動脈一本の CABG 再手術患者でも, 臨床症状 は改善し， RI 検査でも確かめられるので，バイオグラ フトを一つであつけることは十分に意味があると考え る.再手術ではバイパスされてない目的の冠動脈がみつ けにくく，その意味であ緊急手術が難しい.

\section{結一語}

再手術も姑息手術であるととを考え，定期に定時手術 として行うべきである. 使用グラフトには内胸動脈等の バイオグラフトを必ず含める，予防的に IABP を使用 し，目的冠動脈発見には，超音波メスの使用が有効であ る. 不完全血行再建でも十分な症状寛解を期待しうる (表 3).

文 献 1) 小原邦義ほか: 循環器科 $20: 247,1986$. 2) Loop, F. D. et al. : Ann. Thorac. Surg. 36: 380, 1983. 3) Lytle, B. W. et al.: J. Thorac. Cardiovasc. Surg. 93 : 847, 1987. 